\title{
MODEL DISCOVERY LEARNING BERBANTUAN GEOGEBRA UNTUK MENINGKATKAN KEMAMPUAN PEMECAHAN MASALAH
}

\author{
Ferdinandus Mone*, Alfonsa Maria Abi \\ *Prodi pendidikan matematika STKIP SOE, NTT, Indonesia
}

\begin{abstract}
Abstrak: Kualitas Pendidikan di daerah tertinggal tidak dapat disamakan dengan pendidikan di daerah maju. Rendahnya kualitas pendidikan di Daerah tertinggal dapat disebabkan karena fasilitas pendidikan yang jauh lebih minim dari pada daerah maju, salah satunya adalah minimnya media pembelajaran. Rendahnya kualitas pembelajaran di sekolah menengah membuat kualitas input ke perguruan tinggi daerah setempat juga ikut rendah sehingga mahasiswa perlu mengejar keteritinggalan pengetahuan yang sudah terlewati. Peran pengajar dalam menghadapi masalah ini dapat di lakukan melalui desain model pembelajaran berbasis masalah berbantuan media sofware untuk mengefektifkan pembelajaran, salah satunya software geogebra. Hasil penelitian dalam menerapkan model Discovery Learnig berbantuan Geogebra menunjukkan bahwa terjadi peningkatan kemampuan pemecahan masalah setelah terjadi proses pembelajaran, terjadinya ketuntasan kemampuan pemecahan masalah dan kemampuan pemecahan masalah mahasiswa yang diajarkan dengan model Discovery learning berbantuan Geogebra lebih baik dari mahasiswa yang diajarkan dengan model konvensional.
\end{abstract}

Kata kunci: Discovery learning, Pemecahan Masalah, Geogebra

\begin{abstract}
The quality of education in remote areas is really different from the quality of education in developed areas. There are many factors cause the low quality of education in remote areas. One important factor that influences the low quality of education is lacking of learning media. The lack of learning media in senior high school causes the input quality to college or higher education (university) in these areas (remote areas) also low that make the student left behind in getting knowledge. The role of teachers in facing this problem is done by designing problem based learning media using software. One of the learning media is geogebra software. The result of the study in applying discovery learning model through geogebra showed that there was a significant ability improvement of problem solving after learning process. The ability improvement in solving the mathematics' problems of the students who are taught by using geogebra learning media is better than those who are taught using conventional learning model.
\end{abstract}

Key Words: Discovery Learning, Problem Solving, Geogebra.

Alamat korespondensi: Karang Siri, Kota Soe, Kabupaten Timor Tengah Selatan, Nusa Tenggara Timur email: Ferdimone@yahoo.com 


\section{PENDAHULUAN}

Nilai rata-rata matematika siswa kelas VIII Indonesia menempati urutan ke-38 dari 42 negara (TIMSS, 2011) sedangakan hasil PISA 2012 lalu mengeluarkan survei bahwa Indonesia menduduki peringkat paling bawah dari 65 negara (PISA, 2012). Indonesia masih jauh tertinggal oleh negara-negara lain di kancah internasional. Dari hasil survey kedua lembaga tersebut, memberikan Gambaran kemampuan matematika siswa Indonesia berada pada tingkatan kognitif mengetahui (knowing) yang merupakan tingkatan terendah menurut kriteria tingkatan kognitif dari Mullis et. al (dalam Masduki, 2013) siswa Indonesia belum dapat menerapkan pengetahuan dasar yang dimiliki untuk menyelesaikan masalah (applying), serta belum mampu memahami dan menerapkan pengetahuan dalam masalah yang kompleks, membuat kesimpulan, serta menyusun generalisasi (reasoning).

Selain kemampuan siswa yang rendah, kemampuan guru dalam menyampaikan materi pembelajaran juga masih rendah. Hal ini terlihat dari hasil Uji Kompetensi Guru (UKG) tahun 2015. Berdasarkan hasil UKG 2015 provinsi Nusa Tenggara Timur (NTT), rata-rata kemampuan guru pada bidang pedagogic dan bidang prfesional adalah 47,07 atau masih dibawah standar minimal rata-rata kemampuan guru yang diharapkan yaitu 55 .
Rata-rata kemampuan guru dalam kedua ranah diatas menempatkan kemampuan guru dalam ranah pedagogic dan professional pada urutan 23 dari 34 provinsi di Indonesia (Kemdikbud, 2015). Berdasarkan hasil tersebut juga menunjukkan bahwa para guru di NTT belum memenuhi standar minimal dalam mengajar sehingga perlu ditingkatkan. Salah satu bentuk kerja sama adalah adanya bentuk kerja sama dengan perguruan tinggi setempat dalam meningkatkan kulaitas pembelajaran.

Sekolah Tinggi Keguruan dan Ilmu Pendidikan (STKIP) Soe sebagai salah satu perguruan tinggi baru di kabupaten TTS terdiri dari 4 program studi, salah satunya adalah program studi Pendidikan Matematika. Berdasarkan data input, mahasiswa STKIP Soe program studi pendidikan matematika kebanyakan berlatar belakang SMK, SMA jurusan IPS dan Bahasa, atauupun mahasiswa yang putus kuliiah dari universitas lainnya serta ketertinggalan dalam IPTEK, dengan kata lain STKIP Soe memiliki input yang kurang baik (STKIP Soe, 2016). Input yang kurang baik membuat para pengajar harus menghadapi mahasiswa dengan penuh kesabaran dalam menanamkan setiap konsep serta perlunya strategi pembelajaran yang mampu memanfaatkan waktu yang tersedia secara efisien. 
Pembelajaran kalkulus di STKIP Soe sangat membutuhkan model dan strategi pembelajaran yang mampu mengaktifkan mahasiswa maupun meningkatkan ketrampilan Dosen dalam pembelajaran. Mata kuliah ini diambil oleh mahasiswa pendidikan matematika baik yang baru mengambilnya dan maupun yang mengulang matakuliah. Mahasiswa yang mengulang terdiri dari dua kelas sedangkan mahasiswa yang baru program terdiri dari satu kelas. Kreatifitas dosen dalam menjalankan pembelajaran demi meningkatkan pemahaman mahasiswa sangatlah memegang peran penting pada matakuliah kalkulus diferensial sebab matakuliah ini menjadi prasyarat untuk matakuliah selanjutnya.

Berdasarkan latar belakang masalah di Atas maka tujuan penelitian ini adalah: (1) Untuk mengetahui ketuntasan belajar materi kalkulus pada kelas yang diajarkan dengan model Discovery Learning berbantuan geogebra; (2) Untuk menganalisis kemampuan pemecahan masalah mahasiswa materi kalkulus yang diajarkan dengan model Discovery Learning berbantuan Geogebra apabila dibandingkan dengan kemampuan pemecahan masalah mahasiswa yang diajarkan dengan model pembelajaran konvensional. Berikut ini adalah kajian teori yang digunakan dalam penelitian ini.

Penemuan (Discovery) merupakan suatu model pembelajaran yang dikembangkan berdasarkan pandangan konstruktivisme. Discovery learning didefinisikan sebagai proses pembelajaran yang terjadi bila materi pembelajaran tidak disajikan dalam bentuk finalnya, tetapi diharapkan mahasiswa mengorganisasi sendiri (Kemdikbud, 2013). Discovery adalah menemukan konsep melalui serangkaian data atau informasi yang diperoleh melalui pengamatan atau percobaan. Teori yang mendukung teori konstrukvis dalam penelitian ini adalah teori penemuan Jerome Bruner. Teori Bruner merupakan salah satu model instruksional kognitif yang sangat berpengaruh yang dikenal dengan belajar penemuan (Discovery learning). Bruner menganggap bahwa belajar penemuan sesuai dengan pencarian pengetahuan secara aktif oleh manusia, dan dengan sendirinya member hasil yang paling baik. Berusaha sendiri untuk mencari pemecahan masalah serta pengetahuan yang menyertainya, menghasilkan pengetahuan yang benar-benar bermakna (Dahar, 1988: 125).

Pernyataan lebih lanjut dikemukakan oleh (Syamsudini , 2012) bahwa Discovery learning adalah suatu model untuk mengembangkan cara belajar aktif dengan menemukan sendiri, menyelidiki sendiri, maka hasil yang diperoleh akan setia dan tahan lama dalam ingatan. Melalui belajar penemuan, mahasiswa juga bisa belajar 
berpikir analisis dan mencoba memecahkan sendiri masalah yang dihadapi. Dalam pembelajaran dengan penemuan, mahasiswa didorong untuk belajar sebagian besar melalui keterlibatan aktif mereka sendiri dengan konsep-konsep dan prinsip-prinsip dan guru mendorong mahasiswa untuk memiliki pengalaman dan melakukan percobaan yang memungkinkan mereka menemukan prinsipprinsip untuk diri mereka sendiri. Pengaplikasian model Discovery learning dalam pembelajaran, terdapat beberapa tahapan yang harus dilaksanakan. Syah (2004:244) mengemukakan langkah-langkah operasional model Discovery learning yaitu langkah persiapan model Discovery Learning, pelaksanaan prosedur Discovery learning. Model Discovery learning berbantuan Geogebra yang didesain dalam penelitian ini tampak dalam Tabel 1.

Dalam menyelesaikan masalah Mahasiswa diberi kesempatan untuk memperoleh pengalaman menggunakan pengetahuan dan keterampilan yang dimilikinya untuk diaplikasikan pada pemecahan masalah yang sifanya tidak rutin dan guru dapat memperoleh banyak informasi tentang kemampuan pemecahan masalah dari hasil evaluasi terhadap mahasiswa. Dalam kegiatan ini aspek-aspek kemampuan matematika mahasiswa seperti penerapan aturan pada masalah yang tidak rutin, menemukan pola, mengeneralisasikan, mengkomonikasi matematika dan lain-lain dapat ditingkatkan kearah yang lebih baik (Suherman, 2003: 91). Suatu masalah biasanya memuat suatu situasi yang mendorong seseorang untuk meyelesaikannya akan tetapi tidak tahu secara langsung untuk menyelesaikannya.

Untuk memperoleh kemampuan dalam pemecahan masalah, seseorang harus memiliki banyak pengalaman dalam menyelesaikan masalah. Berbagai hasil penelitian menunjukan bahwa mahasiswa yang lebih banyak diberi latihan soal pemecahan masalah memiliki nilai lebih tinggi dalam tes pemecahan masalah dibandingkan dengan mahasiswa diberikan sedikit latihan (Suherman, 2003: 93). Dengan demikian guru perlu mendesainkan suatu model pembelajaran yang mengaktifkan mahasiswa dalam mengerjakan banyak latihan soal pemecahan masalah.

Menurut (Polya dalam Budi, 2004: 2) solusi soal pemecahan masalah memuat empat langkah penyelesaian yaitu memahami masalah, merencanakan penyelesaian, menyelesaiakan masalah sesuai dengan rencana, dan melakukan pengecekan kembali terhadap semua langkah yang telah dikerjaka

Dalam pembelajaran kalkulus diferensial, konsep dan soal-soal yang diberikan selalu berkaitan dengan masalah kehidupan sehari-hari, oleh sebab itu dalam menye- 
lesaikan masalah kalkulus diferensial dapat masalah sesuai dengan rencana, dan diselesaikan dengan langkah-langkah penye- melakukan pengecekan kembali

lesaian masalah yaitu memahami masalah, Berikut ini adalah contoh penyelesian masamerencanakan penyelesaian, menyelesaikan lah yang diberikan.

Tabel 1. Desain model Discovery berbantuan Geogebra

\begin{tabular}{lll}
\hline Langkah & \multicolumn{2}{l}{ Kegitan } \\
\hline $\begin{array}{l}\text { Persiapan model } \\
\begin{array}{l}\text { Discovery learning } \\
\text { berbantuan geoge- }\end{array}\end{array}$ & a. & $\begin{array}{l}\text { Menentukan tujuan pembelajaran dan penggunaan penyampaian cara penggunaan } \\
\text { geogebra dalam menyelesaikan masalah } \\
\text { bra }\end{array}$ \\
& c. & $\begin{array}{l}\text { Melakukan identifikasi karakteristik mahasiswa termasuk ketersediaan media } \\
\text { berupa laptop yang dimiliki mahasiswa }\end{array}$ \\
& d. & $\begin{array}{l}\text { Memgemban materi pembelajaran (menyiapkan Lembar kerja mahasiswa) } \\
\text { tuan Geogebrauntuk dipelajari mahasiswa. }\end{array}$
\end{tabular}

aplikasi model 1) Stimulation (stimulasi/pemberian rangsang)

Discovery learning Pada tahap ini mahasiswa dihadapkan pada sesuatu yang menimbulkan kebingungan, kemudian dilanjutkan untuk tidak memberi generalisasi, agar timbul keinginan untuk menyelidiki sendiri. Dosen dapat memulai dengan mengajukan pertanyaan, anjuran membaca buku, dan modul pratikum penggunaan geogebra dan lainnya yang mengarah pada persiapan pemecahan masalah.

2) Problem statemen (pernyataan/identifikasi masalah)

Dosen memberikan kesempatan kepada mahasiswa untuk mengidentifikasi masalah-masalah yang relevan dengan bahan pelajaran, kemudian salah satunya dipilih dan dirumuskan dalam bentuk hipotesis

3) Data collection (pengumpulan data)

Tahap ini mahasiswa diberi kesempatan untuk mengumpulkan berbagai informasi yang relevan, membaca literatur, mengamati objek, wawancara, melakukan uji coba berbantuan geogebra untuk menjawab pertanyaan atau membuktikan benar tidaknya hipotesis.

4) Data processing (pengolahan data)

Mahasiswa malakukan kegiatan mengolah data dan informasi yang telah diperoleh melalui wawancara, observasi dan sebagainya dengan bantuan software Geogebra. Tahap ini berfungsi sebagai pembentukan konsep dan generalisasi, sehingga mahasiswa akan mendapatkan pengetahuan baru dari alternatif jawaban yang perlu mendapat pembuktian secara logis.

5) Verification (pembuktian)

Pada tahap ini mahasiswa melalakukan pemeriksaan secara cermat untuk membuktikan benar atau tidaknya hipotesis yang ditetapkan tadi dengan temuan alternatif dan dihubungkan dengan hasil pengolahan data.

6) Generalization (menarik kesimpulan)

Tahap generalisasi/menarik kesimpulan adalah proses menarik sebuah kesimpulan yang dapat dijadikan prinsip umum dan berlaku untuk semua kejadian atau masalah yang sama, dengan memperhatikan hasil verifikasi. 
Tabel 2. Langkah penyelesaian masalah

Langkah Penyelesaian

Kegitan Mahasiswa

1) Memahami - mahasiswa harus mengerti semua kata yang terdapat dalam soal masalah pemecahan masalah tersebut. Jika tidak, carilah indeks, kamus, defenisi dan lain sebagainya,

- mahasiswa harus mengetahui apa yang dicari atau ditanya,

- Mahasiswa mampu menyajikan soal dengan kata-kata sendiri atau cara lain yang lebih sederhana,

- Dapat menggunakan gambar sebagai bantuan, atau aplikasi Geogebra

- mahasiswa harus mengetahui apakah informasi cukup untuk menyelesaikan soal atau malah informasi berlebihan

- mahasiswa harus mengetaui apakah ada yang perlu dicari sebelum mencari jawab dari soal.

2) Merencanakan mencoba salah satu strategi yang digunakan untuk menyelesaikan soal yang penyelesaian dihadapi. Bila strategi pertama gagal, coba lagi strategi yang baru sampai berhasil. Semakin banyak pengalaman mencoba strategi, semakin baik kemampuan menyelesiakan masalah. Pada langkah ini strategi dapat diperoleh dari gambar atau aplikasi Geogebra yang digunakan.

3) Menyelesaikan Mahasiswa dengan hati-hati menjalankan rencana penyelesian pada masalah sesuai langkah sebelumnya.

dengan rencana

4) Melakukan

pengecekan kembali berarti pengecekan atas apa yang telah dilakukan dari pengecekan langkah 1 sampai dengan 3 apakah sudah tepat atau belum, jika belum kembali maka segeralah diperbaiki.

Soal

Pakar biologi telah mengamati bahwa laju mengerik jangkrik jenis tertentu nampaknnya terkkait dengan suhu. Tabel menunjukkan laju pengerikan untuk beragam suhu.

\begin{tabular}{|c|c|c|c|}
\hline $\begin{array}{c}\text { Temperature } \\
(\mathrm{oF})\end{array}$ & $\begin{array}{c}\text { Chirping rate } \\
(\text { chirps/min })\end{array}$ & $\begin{array}{c}\text { Temperature } \\
(\mathrm{oF})\end{array}$ & $\begin{array}{c}\text { Chirping rate } \\
\text { (chirps/min) }\end{array}$ \\
\hline 50 & 20 & 75 & 140 \\
55 & 46 & 80 & 173 \\
60 & 79 & 85 & 198 \\
65 & 91 & 90 & 211 \\
70 & 113 & & \\
\hline
\end{tabular}

Carilah laju mengerik jangkrik pada suhu 100F! 


\begin{tabular}{|cccc|}
\hline \multicolumn{4}{|c|}{ Penyelesaian } \\
\hline $\begin{array}{c}\text { Memahami masalah } \\
\text { Diketahui laju mengerik jengkrik tertentu tampak seperti tabel berikut }\end{array}$ & \\
\hline $\begin{array}{c}\text { Temperatur ( } \\
\left.{ }^{0} \boldsymbol{F}\right)\end{array}$ & $\begin{array}{c}\text { Laju mengerik (banyak- } \\
\text { nya mengerik/menit) }\end{array}$ & $\begin{array}{c}\text { Temperatur } \\
\left({ }^{\circ} \boldsymbol{F}\right.\end{array}$ & $\begin{array}{c}\text { Laju mengerik (ban- } \\
\text { yaknya } \\
\text { mengerik/menit) }\end{array}$ \\
\hline $\mathbf{5 0}$ & 20 & 75 & 140 \\
$\mathbf{5 5}$ & 46 & 80 & 173 \\
$\mathbf{6 0}$ & 79 & 85 & 189 \\
$\mathbf{6 5}$ & 91 & 90 & 211 \\
$\mathbf{7 0}$ & 113 & 100 & $\ldots . ?$ \\
\hline
\end{tabular}

Ditanya: berapakah laju mengerik jangkrik pada suhu $100^{\circ} \mathrm{F}$

Merencanakan penyelesian

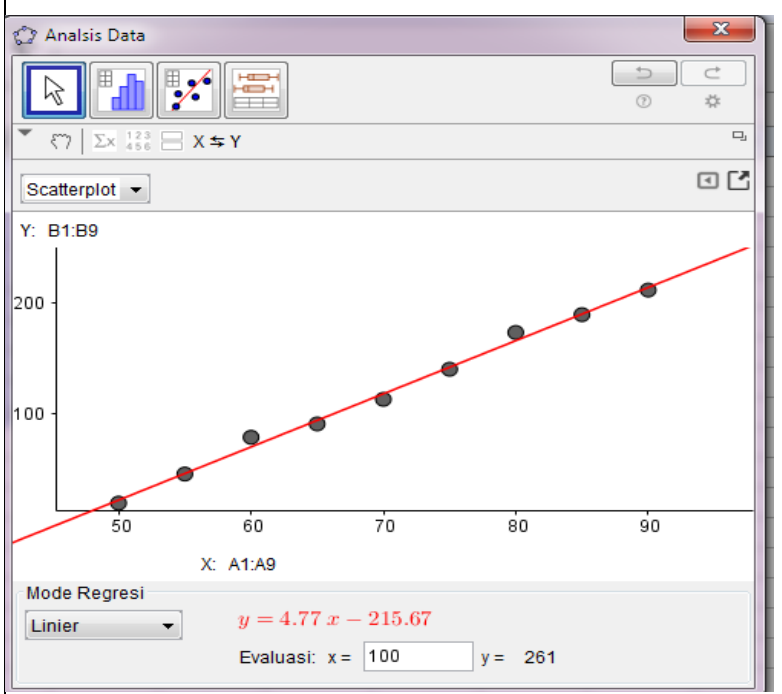

Untuk memperoleh fungsi yang menyatakan hubungan antara suhu dan laju mengerik maka digunakan alat bantu geogebra sehingga fungsi yang diperoleh mampu menafsir laju mengerik dengan kesalahan terkecil. Analisis yang digunakan adalah analisis regresi dua variable

\section{Melaksanakan Rencana}

berdasarkan analisis error dan kesesuaian fungsi maka fungsi yang paling tepat dan sederhana untuk menyetakan hubungan suhu dan laju mengerik adalah fungsi linear dengan persamaan fungsi

$\mathrm{y}=4,77 \mathrm{x}-215,67$ sehingga dapat di perkirakan bahwa laju mengerik jangkrik pada suhu $100^{\circ} \mathrm{F}$ adalah $261 \mathrm{kali} / \mathrm{menit}$

Melihat kembali

Dengan melakukan pengecekan langkah demi langkah maka strategi yang digunakan dalam menyelesiakan masalah sudah tepat. Jadi laju mengerik jangkrik pada pada suhu $100^{\circ} \mathrm{F}$ adalah 261 $\mathrm{kali} / \mathrm{menit}$

\section{METODE PENELITIAN}

Jenis penelitian ini adalah penelitian kuantitatif model true-experimental yang didesain dalam bentuk pre-test and post-test

control-group design (Sugiyono, 2012:79).

Desain penelitian disajikan pada Gambar 1. 


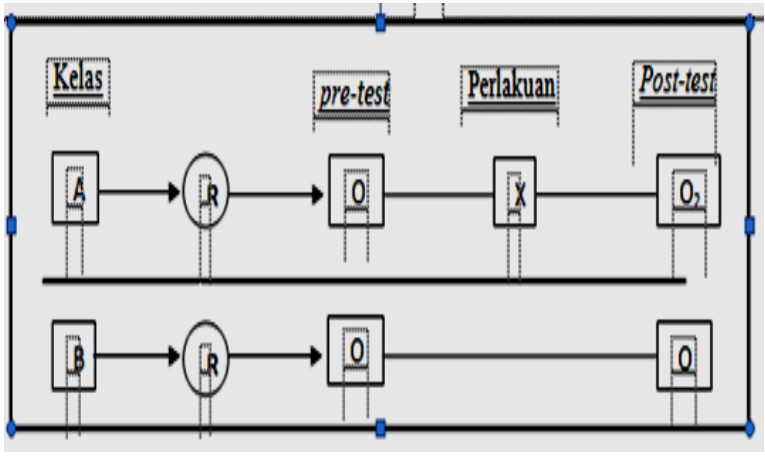

Gambar 1. Desain Penelitian

Populasi penelitian adalah mahasiswa STKIP SoE yang mengambil mata kuliah kalkulus diferensial yang terdiri dari 3 kelas dengan Teknik pengambilan sampel yang dipakai dalam penelitian ini adalah cluster random sampling. Hasil dari cluster random sampling ini adalah mahasiswa semester IV kelas A dan mahasiswa semester IV kelas B. pada penelitian ini yang menjadi kelas dengan model Discovery learning dan kelas Mahasiswa Semester IV B sebagai kelas dengan model konvensional.

Data penelitian untuk menganalisis keefektifan model pembelajaran Discovery learning berbantuan geogeba dalam meningkatkan kemampuan pemecahan diperoleh melalui observasi, wawancara, Tes kemampuan pemecahan masalah dan Lembar kerja mahasiswa demi. Sebelum penelitian dilakukan soal Tes Kemampuan Pemecahan Masalah (TKPM) diujicobakan terlebih dahulu. Hasil uji komudia dianalisis untuk mengetahui tingkat validitas dan reli- abilitas soal tes. Banyaknya butir soal yang diujicobakan adalah 10 butir soal dan diperoleh 6 butir soal yang valid dan mencakup semua indikator dalam mengukur kemampuan pemecahan masalah Mahasiswa, selain itu keenam butir soal tersebut reliabel sehingga keenam butir soal tersebut layak dijadikan soal Tes kemampuan Pemecahan Masalah.

Pelaksanaan penelitian dimulai dari menyebarkan soal pretes untuk mengetahui kemampuan awal kedua kelas tersebut. Hasil dari pretees menunjukkan bahwa data kemampuan pemecahan masalah berdistribusi normal, rata-rata kemampuan pemecahan masalah dari kedua kelas tersebut sama, sebaran kemampuan kedua kelas tersebut sama sehingga hasil penelitian nantinya dapat merepresentasikan populasi. Brikut ini adalah hasil uji kesamaan rata-rata dari hasil pretes.

Tabel 3. Uji homogenitas dan kesamaan rata-rata pretes kemampuan pemecahan masalah

\begin{tabular}{|c|c|c|c|c|c|c|}
\hline & & \multicolumn{2}{|c|}{$\begin{array}{c}\text { Levene's Test } \\
\text { for Equality of } \\
\text { Variances } \\
\end{array}$} & \multicolumn{3}{|c|}{$\begin{array}{l}\text { t-test for Equality of } \\
\text { Means }\end{array}$} \\
\hline & & $\mathrm{F}$ & Sig. & $\mathrm{t}$ & df & $\begin{array}{l}\text { Sig. (2- } \\
\text { tailed) }\end{array}$ \\
\hline \multirow[t]{2}{*}{$\begin{array}{l}\text { NILAI } \\
\text { PRET } \\
\text { ES }\end{array}$} & $\begin{array}{l}\text { Equal } \\
\text { variances } \\
\text { assumed }\end{array}$ & .004 & .950 & 1.803 & 38 & .079 \\
\hline & $\begin{array}{l}\text { Equal } \\
\text { variances not } \\
\text { assumed }\end{array}$ & & & 1.803 & 35.668 & .080 \\
\hline
\end{tabular}


Nilai singifikan uji homogenitas adalah $0,950>0,05$ dan nilai singnifikan uji kesamaan rata-rata adalah $0,079>0,05$ sehingga diperoleh sebaran data homogen dan ratarata kemampuan pemecahan masalah sebelum diberi perlakuan sama.

\section{PEMBAHASAN}

Untuk mengetahui keefektifan model pembelajaran Discovery berbantuan Geogebra maka kelas A diajarkan menggunakan model pembelajaran Discovery berbantuan Geogebra sedangkan kelas B dijadikan kelas kontrol yang diajarkan dengan model konvensional. Data TKPM dianalis untuk mengetahui kenormalan dari data dan diperoleh data beristribusi normal. Uji normalitas data menggunakan uji Kolmogorof smirnov (Sukestiarno, 2013). Hasil uji normalitas data ditunjukkan dalam Tabel 4

Tabel 4. Uji normalitas hasil kemampuan pemecahan masalah

\begin{tabular}{|c|c|c|}
\hline \multicolumn{3}{|c|}{ One-Sample Kolmogorov-Smirnov Test } \\
\hline \multicolumn{3}{|c|}{ NILAI_POSTES } \\
\hline $\mathrm{N}$ & & 40 \\
\hline \multirow{2}{*}{$\begin{array}{l}\text { Normal } \\
\text { Parameters }^{a}\end{array}$} & Mean & 72.5500 \\
\hline & Std. Deviation & 10.48797 \\
\hline \multirow{3}{*}{$\begin{array}{l}\text { Most Extreme } \\
\text { Differences }\end{array}$} & Absolute & .141 \\
\hline & Positive & .096 \\
\hline & Negative & -.141 \\
\hline \multicolumn{2}{|c|}{ Kolmogorov-Smirnov Z } & .893 \\
\hline \multicolumn{2}{|c|}{ Asymp. Sig. (2-tailed) } & .403 \\
\hline a. Test distribu & is Normal. & \\
\hline
\end{tabular}

Berdasarkan hasil uji pada Tabel 4 . diperoleh nilai signifikan 0,403 >0,05 sehing- ga data berdistribusi normal, dengan demikian uji parametrik dipakai untuk menguji hipotesis penelitian. Berikut ini adalah rincian uji hipotesis penelitian

\section{Uji ketuntasan.}

Uji ketuntasan individual digunakan untuk mengetahui apakah pencapaian kemampuan pemecahan masalah mahasiswa di kelas dengan model Discovery learning berbantuan geogebra telah mencapai minimal 70. Analisis uji ketuntasan menggunakan one sample t test (Sukestiarno, 2013). Berdasarkan data yang diperoleh, hasil analisis dari uji ketuntasan tampak seperti pada Tabel 5

Tabel 5. Hasil uji ketuntasan tes kemampuan pemecahan masalah

\begin{tabular}{cccc}
\hline \multicolumn{4}{c}{ One-Sample Test } \\
& $\mathrm{t}$ & \multicolumn{3}{c}{ Test Value $=70$} & df & Sig. (2-tailed) \\
POST_EKS & 2.125 & 19 & .047 \\
\hline
\end{tabular}

Uji ketuntansan menggunakan uji one sample t test menunjukkan bahwa nilai $\mathrm{t}$ hitung $=2.125>\mathrm{t}$ tabel $=1,729$ sehingga diperoleh kesimpulan kemampuan pemecahan masalah mahasiswa yang diajarkan dengan model Discovery learning berbantuan geogebra tuntas secara signifikan. Ketuntasan kemampuan pemecahan masalah didukung oleh pembelajaran yang efisien serta penggunaan media pembelajaran Geogebra dalam 
memhami setiap konsep yang diberikan.

Salah satu contoh hasil karya mahasiswa dalam membuktikan konsep limit menggunakan geogebra tampak seperti gambar dibawah ini.
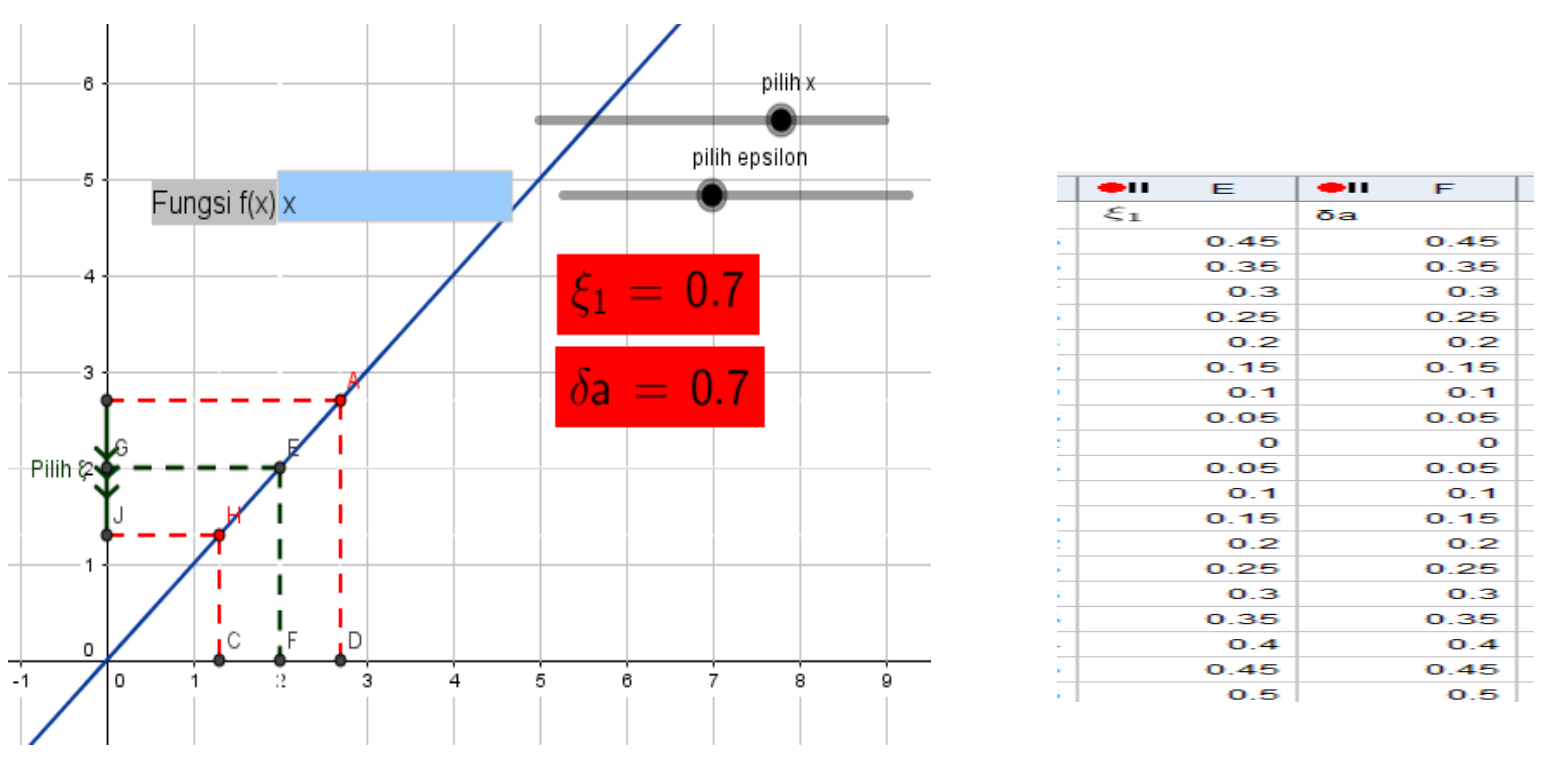

Gambar 2. Hasil Uji t

Mahasiswa dengan penuh semangat mempresentasikan hasil mereka dengan mengatakan berdasarkan tabel hasil animasi nilai $\varepsilon_{1}$ (memilih sembarang nilai $\varepsilon_{1}$ ) diperoleh nilai $\delta_{1}=\varepsilon_{1}$ dengan demikian terbukti bahwa $\lim _{x \rightarrow 2}(x)=2$.

\section{Uji banding}

Uji banding digunakan untuk membandingkan rataan suatu variabel antara data kelas dengan model Discovery learning dan data dari kelas dengan model konvensional. Hasil dari uji banding tampak seperti tabel 7. berikut.
Tabel 7. Hasil uji banding kemampuan pemecahan masalah

Independent Samples Test

Levene's

Test for

Equality of

Variance t-test for Equality of $\mathrm{s} \quad$ Means

Sig. (2-

F Sig. $t$ df tailed)

\begin{tabular}{llrrrrr}
\hline NILAI & Equal & 2.55 & .11 & 2.35 & 38 & .024 \\
POS & variances & 3 & 8 & 8 & & \\
TES & assumed & & & & & \\
& Equal & & & 2.35 & 24.18 & \\
$\quad$ variances not & & & 8 & 0 & .027 \\
$\quad$ assumed & & & & & \\
\hline
\end{tabular}


Berdasarkan data pada Tabel 4.3. diperoleh nilai $t$ hitung $=2,358$. Nilai $t$ hitung dibandingkan dengan nilai t tabel dengan $\alpha$ $=5 \%$ dengan derajat kebebasan $n_{1}+n_{2}-2$ dan diperoleh hasil dari $t$ tabel $(38 ; 0,05)$ $=1,681$. Nilai $t$ hitung $>t$ tabel sehingga di- peroleh kesimpulan rata-rata kemampuan pemecahan masalah mahasiswa yang diajarkan dengan model Discovery berbantuan geogebra lebih baik dari mahasiswa yang diajarkan dengan model konvensional

\section{Contoh masalah.}

Gambar memperlihatkan lampu yang terletak 3 satuan di bagain kanan sumbu $y$ dan bayangan yang diciptakan oleh daerah eliptik $x^{2}+4 y^{2} \leq 5$. Jika titik $(-5,0)$ berada di ujung bayangan seberapa jauh di atas sumbu $x$ letaklampu?

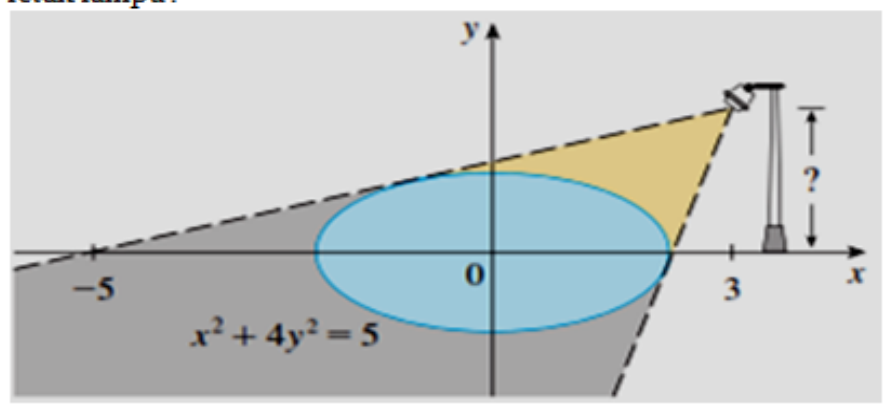

\section{Jawaban mahasiswa}
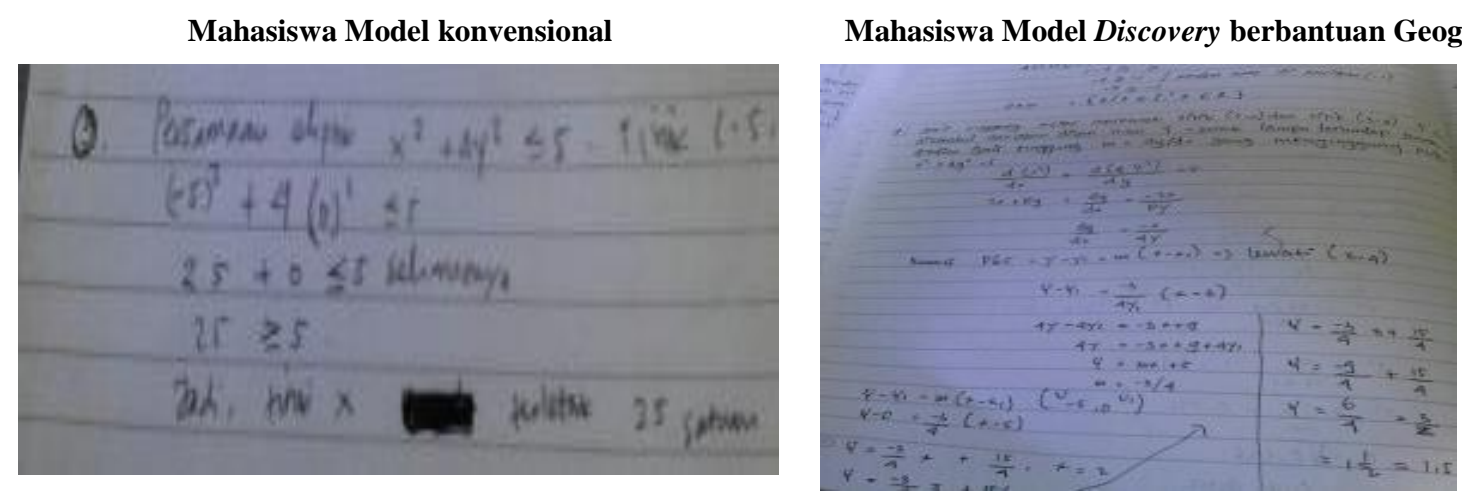

Hasil analisis yang menunjukkan bahwa rata-rata kemampuan pemecahan masalah mahasiswa yang diajarkan dengan model Discovery berbantuan geogebra lebih baik dari model konvensional disebebkan karena mahasiswa yang di-

ajarkan dengan model Discovery lebih terbiasa menyelesaiakan masalah dan dapat memilih berbagai strategi penyelesaian masalah termasuk penggunaan geogebra sebagai alat bantu merancang strategi penyelesaian masa- 
lah. Kreatifitas dan keaktifan mahasiswa pada model Discovery berbantuan geogebra juga lebih baik dari model konvensional, hal ini terlihat dari hasil kerja kelompok dengan presentasi hasil yang maksimal. Peningkatan kretifitas mahasiswa yang terjadi dalam penelitian ini sejalan dengan penelitian yang dilakukan oleh Aryuni pada Kelas XII IPA SMA Negeri Se-Kabupaten Kudus Tahun Pelajaran 2013/2014 (Aryuni, 2014).

\section{a. Uji peningkatan}

Uji peningkatandigunakan untuk mengetahui peningkatan kemampuan pemecahan masalah terhadap mahasiswa yang diajarkan dengan model Discovery learning berbantuan geogebra. Analisis statistik yang digunakan adalah paired sample t tes (Sukestiarno, 2013). Hasil analis uji t dua sampel berpasangan tampak pada tabel 7 .

Tabel 7. Uji peningkatan kemampuan pemecahan masalah

\section{Paired Samples Test}

\begin{tabular}{llccc} 
& & $\mathrm{t}$ & \multicolumn{2}{c}{$\begin{array}{c}\text { Sig. (2- } \\
\text { tailed) }\end{array}$} \\
\hline $\begin{array}{l}\text { Pair } \\
1\end{array}$ & $\begin{array}{l}\text { NILAI_POSTES - } \\
\text { NILAI_PRETES }\end{array}$ & 14.581 & 39 & .000 \\
\hline
\end{tabular}

Berdasarkan tabel 4.4. diperoleh nilai signifikan $0,00<0,05$ sehingga diperoleh kesimpulan bahwa terdapat peningkatan kemampuan pemecahan masalah setelah diajarkan dengan model Discovery learning berbantuan geogebra. Berikut ini adalah gratik yang menunjukkan terjadinya peningkatan kemampuan pemecahan masalah setelah diajarkan dengan model Discovery learning berbantuan geogebra. Hasil peningkatan kemampuan pemecahan masalah dideskripsikan pada diagram garis berikut

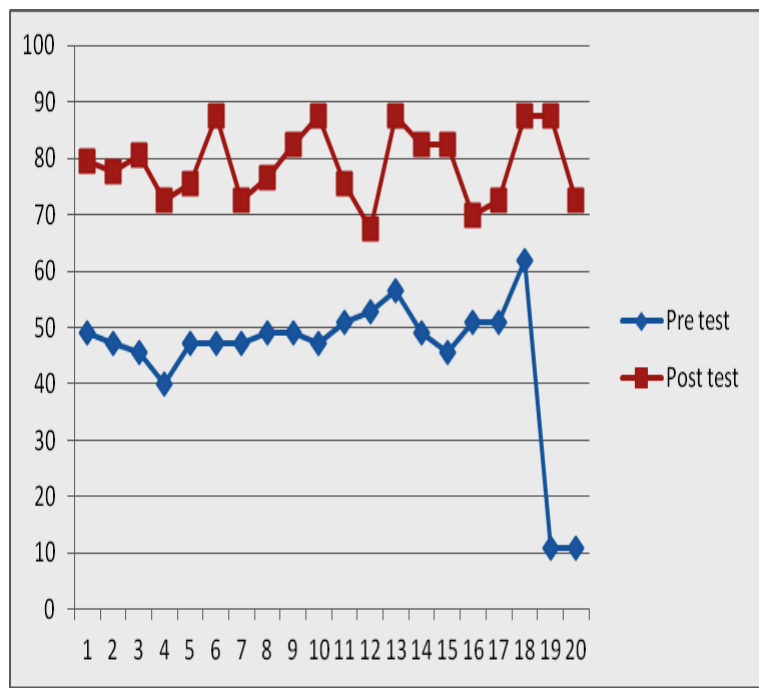

Gambar 3. Diagram peningkatan kemampuan pemecahan masalah

\section{KESIMPULAN}

Berdasarkan hasil pembahasan maka penelitian ini mempunyai kesimpulan bahwa model Discovery learning berbantuan geogebra efektif untuk meningkatkan kemampuan pemecahan masalah mahasiswa STKIP Soe, hal ini terlihat dari (a) kemampuan pemecahan masalah mencapai; (b) 
kemampuan pemecahan masalah siswa kelas yang diajarkan dengan model Discovery learning berbantuan geogebra lebih baik daripada siswa yang diajarkan dengan model konvensional; (c) terjadi peningkatan peningkatan kemampuan pemecahan masalah setelah diajarkan dengan model Discovery learning berbantuan geogebra pada materi kalkulus.
Berdasarkan hasil teori dan pengalaman dalam melaksanakan penelitian maka saran peneliti adalah perlunya strategi yang tepat dalam mengefektifkan pembelajaran dan mengefisiensi waktu baik dari metode, strategi maupun media lain yang dapat diinovasi sesuai dengan kebutuhan, terutama dalam memahami konsep dan menyelesiakan masalah.

\section{DAFTAR PUSTAKA}

Aryuni Puji. (2014). "Eksperimentasi Model Pembelajaran Kooperatif Tipe Teams Games Tournament Dan Student Teams Achievement Division Berbantuan Media Geogebra Pada Materi Program Linear Ditinjau Dari Kreativitas Belajar Siswa Kelas Xii Ipa Sma Negeri Se-Kabupaten Kudus Tahun Pelajaran 2013/2014”. Jurnal Elektronik Pembelajaran Matematika, 2 (3): 270 - 280.

Budi, S. W. (2004). Langkah awal menuju olimpiade matematika. Jakarta: Ricardo.

Dahar, R.W.(1988). Teori-Teori Belajar. Erlangga. Jakarta.

Kemdikbud, (2013). Daftar peringkat UKG 2015. Jakarta

Kemdikbud, (2013). Model pembelajaran penemuan. Jakarta

Masduki. (2013). Level Kognitif Soal-Soal Buku Pelajaranmatematika SMP. Penguatan Peran Matematika dan Pendidikan Matematika untuk Indonesia yang Lebih Baik: 421-428. Yogyakarta: FMIPA UNY

Mullis, et.al. (2011). TIMSS 2011 International Results in Mathematics. USA: TIMSS \& PIRLS International Study Center

PISA. (2012). What Students Know and Can Do: Student Performance in Mathematics, Reading and Science, Summarises the Performance of Students in PISA 2012 , 1:5-6. OECD: $\quad$ http://www.oecd.org/pisa/keyfindings/pisa-2012-results-volume-i.htm. (diunduh tanggal 4 Agustus 2014).

Sardiman, A.M. (2008). Interaksi dan Motivasi Belajar Mengajar. Jakarta: Raja Grafindo Persada

Sugiyono. (2012). Metode Penelitian Pendidikan Pendekatan Kuantitatif, Kualitatif, dan R \& $D$. Bandung: Alfabeta. 
Suherman, dkk. (2003). Strategi Pembelajaran Matematika Kontemporer. Bandung: UPI. Fakultas pendidikan matematika dan ilmu pengetahuan alam (Jurusan pendidikan matematika).

Sukestiyarno. (2013). Olah Data Penelitan berbantuan SPSS. Semarang: UNNES.

Syah, M., (1996). Psikologi Pendidikan Suatu Pendekatan Baru. Bandung: PT Remaja Rosdakarya.

Syamsudini , (2012). Aplikasi Metode Discovery Learning dalam Meningkatkan Kemampuan Memecahkan Masalah, Motivasi Belajar dan Daya Ingat Mahasiswa. 